\title{
Analisis Perbedaan Revenue Bunga Bank Konvensional Dengan Bagi Hasil Bank Syariah (Studi PT Bank Maybank Tbk dan PT Bank BRI Syariah Tbk)
}

\author{
Budi Rustandi Kartawinata ${ }^{1}$, Candra Wijayangka ${ }^{2}$, Muhammad Hasan Rabbani ${ }^{3}$ \\ Universitas Telkom \\ budikartawinata@telkomuniversity.ac.id
}

\begin{abstract}
Financial institutions divided into two, conventional banking and sharia banking. The fundamental thing that distinguishes between conventional and sharia financial institutions lies in the return and profit sharing provided by customers to financial institutions and / or provided by financial institutions to customers (Muhamad, 2014). Operational activities of sharia banks use the Profit Sharing Principle. This research was conducted in order to find out Revenues comparison between interest given by Bank Maybank with Profit Sharing given by Bank BRI Syariah. The purpose of this study is to find out whether there is a difference between the ratio of Revenue and analyze which greater revenue gave from Bank Maybank Interest to Profit Sharing gave from Bank BRI Syariah. The research method used in this research is qualitative method, and data collection technique using secondary data which researcher use data of financial report at bank Maybank and BRI Syariah for saving from 2012-2016. Data analysis technique used in this study is by using $T$ test, which divided into three, normality test, homogeneity test and independent test. The revenues comparison between conventional bank interests were different to profit sharing given by sharia bank. Profit sharing given by Syariah Bank is greater because Conventional Bank uses tier system while Syariah Bank does not.
\end{abstract}

Keyword: Revenue Saving Deposit Bank Konvensional Bank Syariah

\section{Pendahuluan}

Pada awal nya perbankan di Indonesia hanya Bank konvensional, yang dimana bank konvensional menerapkan sistem bunga. Dikarenakan mayoritas masyarakat Indonesia beragama Islam dan bunga dalam Bank konvensional tidak sesuai dengan aturan perekenomian islam, maka pemerintah mulai ingin menerapkan sistem yang dimana dalam pembiayaan dan sistem bagi keuntungan sesuai dengan perekonomian Islam

Bank syariah awal nya dipandang sebelah mata, bahkan dianggap sebagai impossible Bank yang tidak mungkin bisa dijalankan, yakni sebuah lembaga keuangan tanpa bunga. Bunga yang selama ini dianggap sebagai penopang pertumbuhan ekonomi suatu bangsa, harus dihilangkan dalam penerapan system Bank Syariah

Setelah melalui serangkaian pengkajian Bank Syariah resmi diperkenalkan kepada masyarakat pada akhir 1991, Bank Syariah pertama di Indonesia adalah Bank Muamalat Indonesia (BMI), berdiri pada tanggal 1 Nopember 1991. Dengan diberlakukannya undang-undang no 7 tahun 1992 tentang perbankan. UU ini memberikan peluang seluas-luas nya untuk pembukaan bank-bank yang beroperasi dengan prinsip syariah

${ }^{1}$ Korespondensi: Budi Rustandi Kartawinata. Universitas Telkom. J1. Telekomunikasi No.1 Bandung . (022) 7564108. budikartawinata@telkomuniversity.ac.id 
Karena itu pemerintah terus mendorong perkembangan bank syariah di Indonesia, oleh sebab itu pemerintah memberlakukan UU No. 10 tahun 1998 tentang perubahan UU No 7 Tahun 1992 tentang perbankan. Perubahan UU tersebut menimbulkan beberapa perubahan yang memberikan peluang yang lebih besar bagi pengembangan bank syariah. Undang-undang tesebut telah mengatur secara rinci landasan hukum serta jenis-jenis usaha yang dapat dioperasikan dan diimplementasikan oleh bank syariah. Undang-undang tersebut juga memberikan arahan bagi bank-bank konvensional untuk membuka cabang syariah atau bahkan mengkonversi diri secara total menjadi bank syariah.

Akhir tahun 1999, bersamaan dengan dikeluarkannya UU perbankan maka munculah bankbank syariah umum dan bank umum yang membuka unit usaha syariah. Sejak beroperasinya Bank Muamalat Indonesia (BMI), sebagai bank syariah yang pertama pada tahun 1992, dengan satu kantor layanan dengan asset awal sekitar Rp. 100 Milyar, maka data Bank Indonesia per 30 Mei 2007 menunjukkan bahwa saat ini perbankan syariah nasional telah tumbuh cepat, ketika pelakunya terdiri atas 3 Bank Umum Syariah (BUS) salah satu nya adalah Bank BRI Syariah 23 Unit Usaha Syariah (UUS), dan 106 Bank Perkreditan Rakyat Syariah (BPRS), sedangkan asset kelolaan perbankan syariah nasional per Mei 2007 telah berjumlah Rp. 29 triliyun.

Hal mendasar yang membedakan antara lembaga keuangan konvensional dengan syariah adalah terletak pada pengembalian dan pembagian keuntungan yang diberikan oleh nasabah kepada lembaga keuangan dan/atau yang diberikan oleh lembaga keuangan kepada nasabah (Muhamad, 2014). Kegiatan operasional bank syariah menggunakan prinsip bagi hasil.

Pada sistem bunga, pendapatan yang diperoleh bersifat statis yang dimana walaupun perusahaan rugi, utang tetap memiliki bunga yang tetap serta jumlah pembayarannya setiap periodenya juga tetap. Pola bagi hasil ini memungkinkan nasabah untuk mengawasi langsung kinerja bank syariah melalui monitoring atas jumlah bagi hasil yang diperoleh dan dalam bagi hasil pendapatan yang diperoleh akan bersifat dinamis menyesuaikan dengan keadaan usaha. Jika usaha yang dilakukan mendapat keutungan besar maka bagi hasil pendapatnnya juga besar, begitu pula sebaliknya. Oleh karenannya bank dengan sistem bagi hasil cenderung hanya akan membiayai usaha dengan keuntungan yang diprediksi besar.

Bank Maybank merupakan satu-satu nya Bank yang dimiliki pihak Asing (Malaysia) yang memiliki bank konvensional dan syariah berdiri sendiri, Maybank juga memiliki urutan no 4 bank se-Asia walaupun Bank Maybank merupakan urutan no 9 dalam bank konvensional Indonesia. Dan dapat dilihat bahwa suku bunga tabungan yang diberikan oleh Maybank lebih besar apabila dibandingkan dengan Bank Mandiri.

Peneliti menggunakan Bank BRI Syariah sebagai bank yang diteliti dikarenakan bank BRI syariah menjadi no 3 bank yang memiliki bank syariah bukan unit usaha syariah yang dimana bank BRI Syariah akan bersaing dengan Bank Mandiri dan Bank Muamalat untuk memajukan Bank syariah. BRI Syariah juga mencatatkan pertumbuhan aset hingga 12,49 persen dari Rp24,23 triliun pada akhir 2015 menjadi Rp27,69 triliun pada ahir 2016. Pertumbuhan tersebut disebabkan oleh naiknya DPK anak usaha BRI itu sebanyak 11,09 persen, dari Rp19,56 triliun menjadi Rp22 triliun dan pembiayaan yang tumbuh 7,6 persen dari Rp16,66 triliun jadi Rp18,04 triliun

Oleh sebab itu peneliti ingin meneliti bagaimana revenue yang didapat oleh Bank Maybank yang menerapkan Sistem bunga, dan Bank BRI syariah sebagai bank syariah oleh sebab itu (Studi Kasus pada Bank Maybank dan Bank BRI Syariah). Dikarenakan sistem bagi hasil lebih menguntungkan dari pada bunga di bank konvensioanal,

\section{Tinjauan Pustaka}

\section{Pengelolaan Keuangan}


Kinerja keuangan perusahaan adalah salah satu dasar penilaian terhadap kondisi keuangan perusahaan yang dapat dilakukan berdasarkan analisis terhadap rasio-rasio keuangan perusahaan (Solikah, Mardani, \& Wahono, 2017). Menurut menteri keuangan Republik Indonesia No. 112/KMK.02/2012, kinerja adalah prestasi kerja berupa keluaran dari suatu kegiatan atau hasil dari suatu program dengan kualitas dan kualitas terukur yang dicapai oleh perusahaan dalam suatu periode tertentu yang mencerminkan tingkat kesehatan dari perusahaan (Abustan, 2009).

\section{Analisis rasio keuangan}

Menurut (Munawir, 200) analisis rasio keuangan merupakan suatu metode analisis untuk mengetahui hubungan dari pokok-pokok tertentu dalam neraca atau laporan rugi laba secara individu atau kombinasi dari kedua laporan tersebut. Analisis rasio keuangan bank adalah untuk menyajikan suatu cara guna mengungkapkan kondisi keuangan, kesehatan dan prestasi usaha suatu bank.

\section{Bank Konvensional}

Secara sederhana bank konvensional adalah bank yang dalam aktivitas nya, baik kegiatan penghimpunan dan penyaluran dana nya, memberikan dan mengenakan imbalan berupa bunga atau sejumlah imbalan dalam persentase tertentu dari dana untuk satu periode tertentu dan produk-produk yang di tawarkan oleh bank konvensional pada kegiataan di sisi funding dan lending mengandung unsur bunga

\section{Bank Syariah}

Bank Syariah ialah bank yang dalam aktivitas nya baik kegiatan penghimpunan dan penyaluran dananya memberikan dan mengenakan imbalan atas dasar prinsip syariah yaitu jual beli dan bagi hasil. Bagi hasil adalah sejumlah imbalan dalam persentase tertentu dari dana untuk satu periode tertentu. Nama bank syariah sebenarnya hanya digunakan di Indonesia saja, bank syariah pada internasional disebut sebagai bank islam

\section{Kerangka Pemikiran dan Hipotesis Penelitian}

Berdasarkan uraian di atas, selanjutnya peneliti merumuskan model kerangka pemikiran seperti yang digambarkan di bawah ini:

\section{Gambar 1. Kerangka Pemikiran}

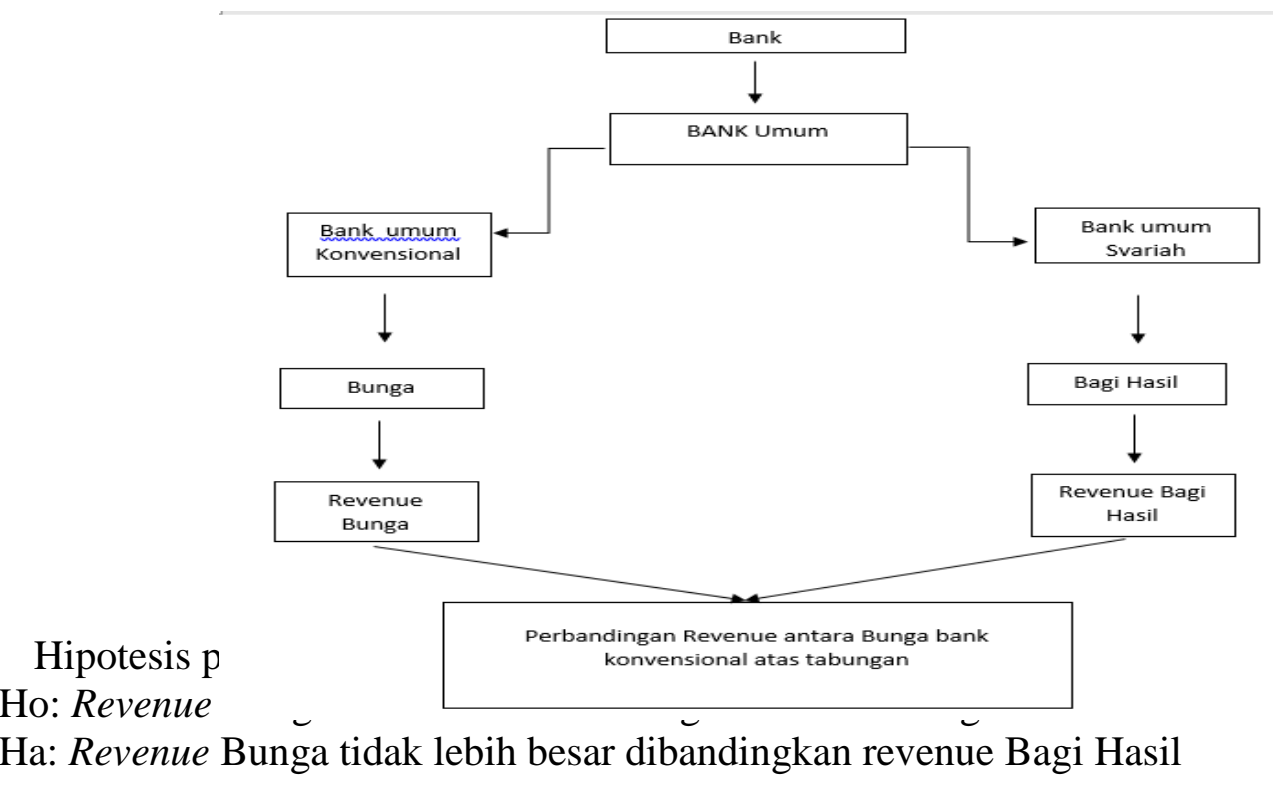

\section{Metode Penelitian}


Jenis penelitian yang akan dilakukan adalah penelitian komperatif yang dimana peneliti melihat perbandingkan revenue dari bunga yang di dapat oleh Maybank atas tabungan dan deposito dengan bagi hasil yang diberikan oleh Bank BRI Syariah atas tabungan dan deposito. Terdapat dua variabel penelitian yang digunakan dalam penelitian ini, yaitu variabel bebas Variabel bebas atau variabel independen (X1) adalah Bunga Bank dan (X2) adalah Bagi Hasil Populasi dalam penelitian ini adalah Bank Maybank dan Bank BRI Syariah Sampel yang digunakan adalah laporan keuangan atas tabungan dari tahun 2012-2016. Jenis data yang diperlukan dalam penelitian ini adalah data sekunder. Teknik pengumpulan data pada penelitian ini menggunakan laporan keungan atas tabungan Pengujian ini dilakukan terhadap dua sampel yang berpasangan (paired). Sampel yang berpasangan diartikan sebagai sebuah sampel dengan subjek yang sama namun mengalami dua perlakuan atau pengukuran yang berbeda (Budisantoso, Totok, \& Nuritomo, 2014). Dalam penelitian ini Pengolahan data untuk membandingkan revenue Bagi hasil yang diterapkan Bank Umum Syariah dengan revenue Bunga yang diterapkan Bank Umum Konvensional menggunakan teknik statistik yang berupa uji beda dua rata-rata (independent sample t-test). Tujuan dari uji hipotesis yang berupa uji beda dua rata-rata pada penelitian ini adalah untuk menentukan menerima atau menolak hipotesis yang telah dibuat.

\section{Hasil}

Uji Normalitas

Berdasarkan hasil uji normalitas diperoleh hasil sebagai berikut:

Tabel 1. Hasil Uji Normalitas

\begin{tabular}{|l|l|r|r|r|r|r|r|}
\hline \multirow{2}{*}{} & \multirow{2}{*}{ Kelompok } & \multicolumn{3}{|c|}{ Kolmogorov-Smirnov $^{\mathrm{a}}$} & \multicolumn{3}{|c|}{ Shapiro-Wilk } \\
\cline { 3 - 8 } & & Statistic & \multicolumn{1}{c|}{$\mathrm{df}$} & \multicolumn{1}{c|}{ Sig. } & \multicolumn{1}{c|}{ Statistic } & \multicolumn{1}{c|}{ df } & \multicolumn{1}{c|}{ Sig. } \\
\hline \multirow{2}{*}{ Nilai } & Bunga & .347 & 5 & .048 & .783 & 5 & .059 \\
\cline { 2 - 8 } & Bagi Hasil & .435 & 5 & .002 & .685 & 5 & .007 \\
\hline
\end{tabular}

Mengacu pada ketentuan bahwa, apabila nilai probabilitas atau signifikansi lebih besar dari 0,05 maka data berdistribusi normal. Berdasarkan hasil analisis data tersebut, dapat disimpulkan bahwa data tes awal dan tes akhir hasil belajar permainan metode praktik distribusi dan metode praktik padat berada pada taraf distribusi Normal.

Uji Homogenitas

Berdasarkan hasil uji multikolinearitas diperoleh hasil sebagai berikut: Tabel 2. Uji Homogenitas

\begin{tabular}{|c|c|c|c|}
\hline \multicolumn{4}{|c|}{ Test of Homogeneity of Variances } \\
\hline \multicolumn{4}{|c|}{ Hasil } \\
\hline $\begin{array}{c}\text { Levene } \\
\text { Statistic }\end{array}$ & df1 & df2 & Sig. \\
\hline .001 & 1 & 8 & .980 \\
\hline
\end{tabular}




\begin{tabular}{|c|c|c|c|c|c|}
\hline \multicolumn{7}{|c|}{ ANOVA } \\
\hline & $\begin{array}{c}\text { Sum of } \\
\text { Squares }\end{array}$ & df & $\begin{array}{c}\text { Mean } \\
\text { Square }\end{array}$ & F & Sig. \\
\hline $\begin{array}{c}\text { Between } \\
\text { Groups }\end{array}$ & 362.043 & 1 & 362.043 & $\begin{array}{c}174.55 \\
8\end{array}$ & .000 \\
\hline $\begin{array}{c}\text { Within } \\
\text { Groups }\end{array}$ & 16.592 & 8 & 2.074 & & \\
\hline Total & 378.635 & 9 & & & \\
\hline
\end{tabular}

Berdasarkan tabel Diketahui bahwa nilai probabilitas (Sig.) untuk tes Bunga Maybank dan Bagi Hasil Bank BRI Syariah berdasarkan nilai rata-rata adalah 0.980 lebih besar dari 0,05 Mengacu pada kriteria keputusan, maka dapat disimpulkan bahwa Bunga yang di terapkan oleh Maybank dan Bagi Hasil Yang diterapkan oleh Bank BRI Syariah mempunyai variansi yang sama, artinya data penelitian adalah Homogen.

Uji Independent Sample T-Test

Berdasarkan hasil uji heteroskedastisitas diperoleh hasil sebagai berikut:

Tabel 3. Uji Independent Sample T-Test

\begin{tabular}{|c|c|c|c|c|c|c|c|c|c|c|}
\hline & & $\begin{array}{l}\text { Leven } \\
\text { for Eq } \\
\text { of } \\
\text { Varian }\end{array}$ & $\begin{array}{l}\text { 's Test } \\
\text { dality } \\
\text { ces }\end{array}$ & t-test for & Equality & f Mean & & & & \\
\hline & & $F$ & Sig. & $\mathrm{T}$ & $\mathrm{df}$ & $\begin{array}{l}\text { Sig. } \\
(2- \\
\text { tailed }) \\
\end{array}$ & $\begin{array}{l}\text { Mean } \\
\text { Difference }\end{array}$ & $\begin{array}{l}\text { Std. Error } \\
\text { Difference }\end{array}$ & $\begin{array}{l}95 \% \text { Confic } \\
\text { Interval of } t \\
\text { Difference }\end{array}$ & $\begin{array}{l}\text { ence } \\
\text { he }\end{array}$ \\
\hline & & & & & & & & & Lower & Upper \\
\hline $\begin{array}{l}\text { Self } \\
\text { Regulated } \\
\text { Learning }\end{array}$ & $\begin{array}{l}\text { Equal } \\
\text { variances } \\
\text { assumed } \\
\text { Equal } \\
\text { variances } \\
\text { not } \\
\text { assumed }\end{array}$ & 0.001 & 0,980 & $\begin{array}{l}-13.212 \\
-13.212\end{array}$ & $\begin{array}{l}8 \\
7.671\end{array}$ & $\begin{array}{l}.000 \\
.000\end{array}$ & $\begin{array}{l}-12.03400 \\
-12.03400\end{array}$ & $\begin{array}{l}.91083 \\
.91083\end{array}$ & $\begin{array}{l}-14.13439 \\
-14.15017\end{array}$ & $\begin{array}{l}-9.93361 \\
-9.91783\end{array}$ \\
\hline
\end{tabular}

Dikarenakan tingkat (sig.2- tailed) sebesar 0,001 dan lebih kecil dibandingkan 0.05 Maka dapat disimpulkan bahwa Revenue Bunga yang diterapkan oleh Maybank tidak lebih besar dibandingka oleh Bagi Hasil Bank BRI Syariah.

Penelitian ini dilakukan untuk mendapatkan jawaban dari pertanyaan-pertanyaan penelitian yaitu:

1. Apakah ada Perbedaan Revenue antara Bunga yang di terapkan oleh Maybank dengan Bagi Hasil yang di terapkan oleh bank BRI syariah?

2. Kedua, Manakah yang memberikan Revenue paling besar antara sistem Bagi Hasil dan Bunga. Peneliti membandingkan revenue yang diberikan oleh kedua sistem tersebut dari tahun 2012 sampe dengan 2016.

Dari hasil pengolahan dan analisis yang telah peneliti lakukan diperoleh hasil bahwa;

1. Terdapat perbedaan revenue antara Bunga yang di terapkan oleh Maybank dengan Bagi Hasil. Hal ini dibuktikan dengan (sig.2- tailed) sebesar 0,001 dan lebih kecil dibandingkan 0.05. Dan dapat dilihat bagaimana kedua bank tersebut melakukan perhitungan revenue dengan 
cara perhitungan yang berbeda, yang dimana Maybank memberikan revenue dangan cara Bunga dan Bank BRI Syariah memberikan revenue dengan cara Bagi Hasil.

2. Revenue yang diberikan oleh Bank BRI Syariah atas sistem Bagi Hasil lebih besar dibandingan dengan Revenue yang diberikan oleh Bank Maybank atas sistem Bunga, hal ini dibuktikan dengan tingkat (sig.2- tailed) sebesar 0,001 dan lebih kecil dibandingkan 0.05.dan juga dapat dilihat bagaimana bank Maybank memberikan bunga atas tabungan berdasarkan sistem tier,yang dimana apabila nasbah menabung kurand dari 1 juta maka Maybank tidak memberikan bunga atas tabungan mereka akan tetapi berbeda dengan Bank BRI Syariah. Bagaimana Bank BRI Syariah memberikan bagi hasil kepada nasabah atas tabugan mereka walapun dana tabungan nasabah tidak lebih dari 1 juta dan kita juga dapat melihat dari persenana rata-rata nisbah yang diberikan oleh bank BRI Syairah setiap tahun lebih besar dibandingkan bunga rata-rata, seperti contoh pada tahun 2016 Bank BRI Syariah memberikan nisbah tabungan sebesar 14,40\% sedangkan Maybank memberikan 2,60\% akan tetapi jumlah tabungan Maybank pada tahun 2016 lebih besar dibandingkan oleh jumlah tabugan bank BRI Syariah. Yang dimana Bank Maybank mendapatkan dana tabungan 18.773.202 (dalam jutaan) dan Bank BRI Syariah mendapatkan 4.179.136 (dalam jutaan) yang dapat disumpulkan bahwa Masih banyak nya masyarakat yang lebih banyak menabung di Bank Maybank dibandingkan menabung di Bank BRI Syariah

\section{Simpulan}

Berdasarkan pengolahan data dan hasil analisis data yang mengacu pada masalah dan tujuan penelitian, maka dapat dirumuskan kesimpulan penelitian sebagai berikut:

Terdapat perbedaan Bunga di Bank Maybank dibandingkan dengan system bagi hasil yang diterapkan oleh Bank BRI Syariah yaitu :

1. Bank Maybank menerapkan system bunga tetap sedangkan Bank BRI Syariah menerapkan sistem bagi hasil dengan kesapakatan system marjin dimuka dengan nasabah nya

2. Bank Maybank berkewajiban membayar bunga kepada nasabahnya tanpa melihat untung rugi bank sedangkan di Bank BRI Syariah untung rugi ditangunggung bersama pihak nasabah dan bank

Terdapat Keuntungan bagi nasabah syariah dibandingkan bank konvensional, yaitu mekanisme bank syariah didasarkan pada prinsip efisiensi dan kebersamaan. Bagi hasil dihitung dari hasil usaha pihak bank dalam megelola uang nasabah,bank dan nasabah membuat perjanjian bagi hasil berupa presentase tertentu untuk nasabah dimana Maybank menerapkan sistem tier dalam pemberian bunga tabungan yang dimana apabila tabungan nasabah kurang dari satu juta maka Maybank tidak memberikan Bunga atas tabungan nasabah sedangkan bank syariah tidak menerapkan system tier walapun tabungan nasabah kurang dari 1 juta maka Bank BRI Syariah memberikan bagi hasil atas tabungan mereka

Akan tetapi masih banyak masyarakat yang berpendapat bahwa Bagi hasil yang dijalankan oleh bank syariah tidak bener bener mengikuti kaidah islam,dan masih banyak juga masyarakat yang berpendapat bahwa bunga lebih menguntungkan dibandingkan bagi hasil

Dan masih banyak nya masyarakat Indonesia yang masih menggunakan bank konvenisonal dalam menyimpan uang meraka dikarenakan Unit-unit bank konvensional dan ATM bank konvensional lebih banyak dibandingkan bank syariah

\section{Daftar Pustaka}

Abustan. (2009). Analisa Perbandingan Kinerja Keuangan Perbankan Syariah Dengan Perbankan Konvensional. Jakarta: Universitas Gunadarma. 
Budisantoso, Totok , \& Nuritomo. (2014). Bank dan Lembaga Keuangan Lain. Jakarta: Salemba Empat.

Muhamad. (2014). Manajemen Dana Bank Syariah. Jakarta: Rajawali Press.

Munawir. (200). Analisis Laporan Keuangan. Yogyakarta : Liberty.

Solikah, H. M., Mardani, R. M., \& Wahono, B. (2017). Analisis Perbandingan Kinerja Keuangan Bank Umum Syariah Dengan Bank Umum Konvensional Di Indonesia (Studi Empiris Pada Perusahaan Perbankan di Bursa Efek Indonesia). Warta Ekonomi, 20. 